\title{
OVERVIEW OF THE STUDENT SATISFACTION LEVEL OF THE PENJASKESREK FKIP UNDANA STUDY PROGRAM IN USING E-LEARNING DURING THE COVID-19 PANDEMIC
}

\author{
Ronald Dwi Ardian Fufu', Erwin S Neolaka², Yudabbirul Arif*3, Al Ihzan \\ Tajuddin $^{4}$, Michael Johannes Hadiwijaya Louk ${ }^{5}$ \\ ${ }^{12345}$ Physical Education, Health And Recreation Department, Faculty of Education and Teachers
} Training, Universitas Nusa Cendana, Indonesia

\section{Info Artikel}

Article History :

Received : November 2021

Revised : December 2021

Accepted : December 2021

Available online :

December 2021

\section{Keywords:}

Covid-19, E-learning, Physical Education Sport, Satisfaction Level

\begin{abstract}
Abstrak
In learning the meaning of motion and its application will be different, of course the consequence is injury. This problem is a description of the problems that occur in the Physical Education Study Program. This can affect the level of student satisfaction in using e-learning at Nusa Cendana University at the study program level. The research method used is a qualitative research method with the type of survey research with a research time of 4 months. Students of the physical education health and recreation study program consisting of semester 2 to semester 8 , where the delegates for each class are 20 people with a total of 80 people. With data collection techniques using observation, questionnaires and documentation. The results of the study can be concluded that the implementation of online lectures during the covid-19 pandemic is the best solution. the calculation of the average value is known that the aspects of comfort, aspects of relationships and competence are in the satisfied category. On the other hand, there is one aspect that is found to be slightly different from other aspects, namely the cost aspect, this aspect is in the less satisfied category. Overall it can be concluded that the Satisfaction Level of Students of the Physical Education Study Program FKIP Nusa Cendana University in Using E-Learning During the Covid-19 Pandemic is in the satisfied category.
\end{abstract}

Corresponding address : Jl. Adi Sucipto Penfui, Penfui,

ISSN 2685-6514 (online)

Maulafa, Kota Kupang, Nusa Tenggara Timur

ISSN 2477-331X (print)

*Corresponding email : yudabbirul@staf.undana.ac.id 


\section{INTRODUCTION}

The government through the Ministry of Education and Culture has issued Circular Letter Number 3 of 2020 concerning Prevention of Covid-19 in Education Units in anticipation of the spread of the Corona virus in various schools and universities. (Kemendikbud, 2020). Following up on the Government's recommendation, the implementation of academic activities during the emergency period for the spread of Covid 19 on campus is carried out to prevent and avoid the spread of the Corona Covid-19 virus which is spreading in several countries including Indonesia.

In the current pandemic situation, it must be admitted that almost all activities that involve many people are felt to be hampered. Even though the government has not implemented a lock down or even implemented a large-scale social restriction (PSSB), it is still very hampered (Yunus \& Rezki, 2020). Many activities that involve many people are limited by rules that follow the health protocols in their respective areas (Fitri et al., 2020). All further activities are recommended to be held online or using internet communication media. Internet communication media makes it very easy for communication to occur properly and quickly, but communication via the internet requires adequate devices to facilitate structured communication.

One of the main functions of learning media is as a teaching aid that also influences the climate, conditions, and learning environment that is arranged and created by the teacher ( $\mathrm{N}$ et al., 2021). Therefore, it can be concluded that learning media are tools, materials or all resources used to convey learning materials from teachers to students in the process of teaching and learning activities.
With the development of science and technology, many media websites are offered to facilitate the continuity of lectures. With the expertise of website makers, they design websites with simple and complete communication features according to the needs of users, namely lecturers and students. However, using the Website requires a data package fee or credit (payment fees) for continuous use of the devices used such as e-learning, zoom meetings, WhatsApp, Skype, Google Drive, Google Meet, Messenger and other features. (Fitriani, 2020).

During the COVID-19 pandemic, many universities are looking for onlinebased lecture solutions for the sake of direct interaction of academic activities (Mahnun, 2018). Nusa Cendana University Kupang-NTT maintains the continuity of lectures by using onlinebased communication media with elearning websites which greatly help the smooth running of academic activities. The use of e-learning is integrated in all faculties to the existing study programs at Nusa Cendana University Kupang-NTT. Since the COVID-19 pandemic, elearning has been a recommended medium for use in academic activities. The leadership of Nusa Cendana University Kupang-NTT together with trusted units or institutions are trying to introduce e-learning through gradual training of lecturers, staff, and students.

Learning using E-Learning is a flexible way of learning, because teachers and students can access E-Learning media without being hindered by time and place to learn. Currently, e-learning programs are becoming a hot topic in the world of education, as technology becomes more sophisticated, it will affect learning methods and will become more sophisticated as well. (Arif, 2020). 
The disadvantage of E-learning is that learning using the E-learning model requires more additional equipment (such as computers, monitors, keyboards, and so on) (Haryanto, 2018). Types of E-learning based on the information technology used and grouped based on technology, namely: Computer Based Training (CBT) This system began to develop in the 80s and is still growing until now. This is supported, among other things, by the development of an increasingly attractive and realistic animation system (e.g. a 3dimensional animation system).

Web Based Training (WBT) This system is a further development of CBT and is based on internet technology (Sattari et al., 2017). So by using this concept, two-way communication can occur between users. However, the smoothness of this learning process depends on high-speed network infrastructure. The obstacle to implementing this concept lies in the fact that some internet networks are fast, some are slow, but not evenly distributed (Sansen et al., 2019).

At the level of study programs at the University of Nusa Cendana Kupang, in general, e-learning has been used for academic activities. With the training provided, lecturers and students are able to use e-learning well. The Penjaskesrek study program at Nusa Cendana University is one of the study programs in the teaching and education faculties that take part in using e-learning as a communication medium for online lectures. E-learning greatly facilitates lecturers in arranging lecture hours according to the approved class schedule, making it easier for lecturers to give open assignments and face-to-face guidance to students. (Setiawan, 2020).
The problem is in the mastery of the psychomotor domain (motion). From the psychomotor realm, students are required to carefully master the types of movement skills gradually with open or direct practice, where if done directly students can understand and be able to gradually integrate motion in simple physical education learning with concepts learned to students later. In general, these concepts can be learned indirectly through e-learning, but there will be different interpretations in the application of these movements, even the worst thing is that the meaning of motion and its application will be different, of course the consequence is injury. Relevant research from Jember University Student Satisfaction Survey Report on Online Learning Even Semester 2019/2020. The problem above is a description of the problems that occur in the Physical Education Study Program. This can affect the level of student satisfaction in using elearning at Nusa Cendana University at the study program level.

Based on the description above, there is a need for further studies related to this issue, because some of us lecturers want to study this issue with the following research title: Overview of Student Satisfaction Levels of the Undana Penjaskesrek Study Program in Using ELearning During the Covid-19 Pandemic.

The novelty of the research that I did is a very important research considering that there is currently a pandemic so that the level of learning satisfaction using E-learning is important for the education at Nusa Cendana University. This research was conducted to see how the level of satisfaction in general is how the level of satisfaction with online learning is when viewed from the understanding of students. 
When compared with similar research, this study uses the latest theory and uses Mendeley as an application that combines various journals so that it is easy to quote here. And this article uses a qualitative method that can explain descriptively related to this so that it can be seen in general and can be used as a reference from other universities.

The reason this research is a study that primarily wants to identify problems from the dimensions of user satisfaction within the scope of the study program, which can later be input for managers to make further improvements in terms of reviewing the level of student satisfaction in using E-Learning, and it can be said that this research is a the latest research in the national scope.

In its use, there are several problems experienced by users in the study program which are felt to be obstacles in the use of e-learning. Furthermore, the goal to be achieved in this research is to find out how the satisfaction level of E-Learning learning for FKIP Undana Penjaskesrek students is so that they can actually see how conditions are during the current pandemic.

\section{METHODS}

This research is a descriptive research using a survey method. Descriptive research is research that only really describes what is or occurs in a certain field, field and area (Kanal Informasi, 2019). The time used in this study was 4 months so that the data were directly analyzed based on the method used. This research will be carried out at the Faculty of Teacher Training and Education, Penjaskesrek Study Program, Nusa Cendana University.
Population is a generalization area consisting of: objects/subjects that have certain qualities and characteristics determined by the researcher to be studied and then draw conclusions (Sugiono, 2016). The sample is part of the number and characteristics possessed by the population (Sugiono, 2014). So the research subjects used in this study were students of the Physical Education Study Program consisting of semester 2 to semester 8 , where the delegates for each class were 20 people in total 80 people.

The data collection techniques used in this research are:

\section{Observation Technique}

In making observations during the Covid-19 Pandemic, researchers only observed secondary data needs such as the presence of research subjects, the use of indirect or online communication media. Another thing that becomes a reference is the openness and certainty of the research problem to be studied (Hasanah, 2017).

\section{Questionnaire}

Questionnaire / Questionnaire is a method of collecting data by giving a set of questions or a written statement to the respondent (Mabesau, 2021). During the covid-19 pandemic, of course there are limits that must be done to maintain the health of researchers and research subjects, therefore data in the form of questionnaires/research questionnaires are distributed online via Google Form in the form of questions related to the data that the researchers want. If there are obstacles or things that allow further explanation, researchers will use face-to-face online meetings using the Zoom Meeting application. 


\section{Documentation}

In collecting data, it must also be accompanied by documentation, so that understanding of the main issues can be obtained (Arif \& Alexander, 2019). This method is intended to obtain data because the documentation is used to test interpretations and materials for predicting thus it is very supportive for the interests of qualitative research. Research documentation data is obtained by researchers directly and indirectly by following health protocols.

This research is qualitative research by analyzing the data to be obtained, the author uses qualitative analysis techniques (metode penelitian kuantitatif, kualitatif,dan R\&D, 2016), namely: Data Reduction, Data Display, Conclusion.

The data obtained in this study will be analyzed using descriptive analysis. After all the data has been collected, the next step is to analyze the data so that a conclusion can be drawn. The data analysis technique in this study uses descriptive quantitative data analysis techniques.

\section{RESULT}

In accordance with the research method used in this study, the researchers validated the research instrument in the form of a questionnaire based on a grid related to the research study being studied. The following is a description of the validation of the research questionnaire:

This research questionnaire grid refers to the problems that occur in the implementation of online lecture activities carried out using e-learning, among others related to:
- Tangibles Aspect (Related to the Facilities and Infrastructure Used)

- Aspect of Reliability (Reliability of Lecturers in Lectures)

- Responsiveness Aspect (Lecturer Response Attitude)

- Assurance (Guarantee treatment for students)

- Empathy Aspect (Understanding the interests of students)

Based on research questionnaires distributed to research samples conducted online using google form, the research data were found as follows::

\section{Description of the Convenience Aspect of Positive Learning Locations}

Based on the description of the statement on the data about the convenience aspect of the learning location, it is known that the highest answer selection by respondents is in the answer (Agree) $=30-35$. In the statement regarding the location of the location for accessing the internet from home, there is an answer (Disagree) which explains that there are some students who have problems accessing the internet from home. On the other hand, the learning atmosphere using e-learning received high answers from respondents, so that the comfort aspect for the category of positive statements had a satisfying impact.

2. The description of the Convenience Aspect of the Study Location is negative

Based on data about the convenience aspect of the study location studied from negative statements where there are the most respondents' answers at (Disagree) $=26$ people and the lowest (Strongly Agree) $=2$ people who answered that they were disturbed when learning was carried out from home. On 
the other hand, the statement does not support that the internet network is well accessed from home, the respondent chooses the answer (Disagree) $=24$, meaning that the internet network is still experiencing problems when accessed from home.

3. Description of the Convenience Aspect of positive statement facilities and infrastructure

Based on data about the comfort aspect in terms of infrastructure for the category of positive statements, respondents chose the highest answer $($ Strongly Agree $)=31$ on the statement that students use cell phones to access elearning. While the answer choices (Disagree) $=31$ are using a laptop to access e-learning. While the choice (Disagree) $=28$, the highest chose the statement that I access e-learning using internet facilities provided by the campus. This means that students always use mobile phones to access e-learning and only a small number of students use campus facilities to access the internet.

4. description of the Convenience Aspect of facilities and infrastructure for negative statements.

Based on data about the comfort aspect in terms of infrastructure for the category of negative statements, respondents chose the highest answer (Agree) $=32$ that often borrowed a friend's cell phone to access e-learning. The answer choices (Agree) $=29$ say that students feel that using laptops is not effective in accessing e-learning. This means that in accessing e-learning students always use a friend's cell phone and most students do not use a laptop to access e-learning
5. Description of the aspect of the communicative relationship between lecturers and students for positive statements

Based on the description of the table above regarding the aspect of the communicative relationship between lecturers and students in statements 11 , 13, 15 and 17 for positive statements, the highest answer choice (Strongly Agree) $=$ 38 that every week or month students fill out internet packages to support lectures. Choice (Strongly Agree) $=31$ that the lecturer is always willing to help students in dealing with problems in using elearning. Choice (Strongly Agree) $=29$ that the Lecturer is always willing to be contacted by telephone, e-mail, WA and so on. Answer choices (Agree) $=26$ that in using e-learning the lecturer is always cooperative with students

6. Description of the aspect of the communicative relationship between lecturers and students for negative statements

Based on the description of the aspect of the communicative relationship between lecturers and students in statements 12, 14, and 16 for negative statements, the highest choice for the answer (Strongly Disagree) $=25$ is every day students insert money to buy internet packages. The following highest answer choices are in the answer (Agree) $=21$ that Lecturers seem indifferent regarding the problems faced by students in accessing elearning, this is followed by answer choices (Disagree) $=20$ that Lecturers seem indifferent regarding the problems faced by students in accessing e-learning learning. The highest answer choice is (Agree) $=29$ that the Lecturer refuses to accept calls, e-mails, WA and so on from students. 
7. Description of the aspect of responsive relationships in serving students for positive statements

Based on the description of the data regarding the aspect of responsive relationships in serving students in statements 18, and 20 for positive statements, the highest answer choice is (Strongly Agree) $=41$ that in delivering material the lecturer uses polite language, and is followed by the highest answer choice (Agree) $=35$ that Lecturers have a high awareness of the use of e-learning.

8. Description of the responsive relationship aspect in serving students 21 for negative statements

Based on the description of the data regarding the aspect of responsive relationships in serving students in statements 19, and 21 for negative statements, the highest answer choice is (Agree) $=31$ that Lecturers are always busy when students ask about their college problems, followed by the highest choice of answers (agree) $=30$ that Lecturers are indifferent to student activities in accessing e-learning

9. Description of the competence aspect of lecturer reliability in lectures for positive statements

Based on the description of the data regarding the competence aspect of lecturer reliability in lectures on statements $22,23,24,26,28,30$, and 32 for positive statements, the highest answer choice (Strongly Agree) $=26$ that the Lecturer understands in accessing e-learning and is followed by $($ Agree $)=26$ that the Lecturer understands in accessing e-learning. Next the highest answer choice (Agree) $=26$ that Lecturers are always active in accessing e-learning. The following answer choices at (Agree) $=28$ that
Lecturers always come on time during lectures using e-learning. The following answer choices at (Strongly Agree) $=27$ that the Lecturer conveys lecture plans, rules, and evaluations through e-learning clearly. The following answer choices at (Strongly Agree) $=31$ that Lecturers always provide (Handouts, e-modules, Video Tutorials, Powerpoints) to support lecture materials. The following answer choices at (Strongly Agree) $=26$ that Lecturers always use easy-to-understand learning methods/models in e-learning. The following answer choices at (Agree) $=$ 33 that the lecturer taught me to skillfully use learning media using e-learning

10. Description of the competence aspect of lecturer reliability in lectures for negative statements

Based on the description of the data on the competence aspect of lecturer reliability in lectures on statements 25, 27, 29, and 31 for negative statements, the highest answer choice is in the answer (Disagree) $=30$ that Lecturers are sometimes busy so that lectures become hampered. The following answer choices at (Agree) $=26$ that the Lecturer only teaches without explaining the lesson plans, rules and conducting evaluations. The highest answer choice is at $($ Agree $)=31$ that Lecturers only tell stories when carrying out online learning. The following answer choices at (Disagree) $=28$ that the lecture method is a good way of delivering material in elearning.

11. Description of the competency aspects of student reliability in lectures for positive statement

Based on the description of the data on the aspect of student reliability competence in lectures in statements 33 , 35,37 , and 38 for positive statements, the highest answer choice is (Strongly Agree) 
$=33$ that students are skilled in accessing and managing e-learning (opening and closing e-learning). learning, doing absent). The following answer choices are at (Agree) $=35$ that With e-learning I understand presenting material online. The following answer choices are (Strongly Agree) and (Agree) the same number $=23$ that I always enter according to the course hours determined by the lecturer in using e-learning. The following answer choices at $($ Agree $)=24$ that I am very happy to use e-learning because it trains focus in learning

12. Description of the aspect of student reliability competence in lectures for negative statements

Based on the description of the data on the aspect of student reliability competence in lectures on statements 34 , 36 and 39 for negative statements, the highest answer choice is (Agree) $=$ The assignment in the form of a video makes me lazy to do it, the next highest answer choice is (Agree) $=24$ that There are so many steps in e-learning that it is difficult for me to present the material. The highest answer choice is (Disagree) $=24$. There are so many steps in e-learning that it is difficult for me to present the material. The following answer choices at (Agree) $=24$ that I tend to be bored and sleepy when using e-learning in learning

\section{Description of the high cost aspect of} data packages for positive statements

Based on the description of the data regarding the high cost aspect of the data package in statements 40,42 , and 43 for positive statements, the highest answer choice is (Agree) $=30$ that the cost of using e-learning for me is very affordable, the following highest answer choices are at (Strongly Disagree) $)=34$ that I often ask my parents for money to buy a data package. The following answer choices at (Agree) $=21$ that $\mathrm{I}$ have received internet data package assistance to access elearning.

14. Description of the high cost aspect of data packages for negative statements

Based on the description of the data regarding the high cost aspect of data packages in statements 41,44 , and 45 for negative statements, the highest answer choice is (Strongly Disagree) $=27$ that $\mathrm{I}$ feel burdened by purchasing data packages because of the high costs. The highest answer choice is at (agree) $=20$ that I don't get internet data package assistance at all. The highest answer choice is at (Strongly Disagree) $=24$ that I sometimes do not attend lectures because there is no internet package.

\section{DISCUSSION}

Describes the achievement of student satisfaction levels in using elearning in online learning in the Penjaskesrek study program, Faculty of Teacher Training and Education, Nusa Cendana University which is reviewed from statement 1 to statement 55 . Following are the details of the description from the table above:

\section{a. Comfort Aspect}

In the aspect of convenience, there are 10 statements answered by the respondents, of the 10 statements for the learning location indicators consisting of statements number 1 to number 5 , the average percentage of answers is $61.73 \%$ with the category Satisfied. While the indicators of facilities and infrastructure consisting of statements number 6 to number 10 obtained an average percentage of answers of $65 \%$ in the satisfied category. When combined, the average percentage of answers obtained 
is 63.59. Therefore, it can be concluded that the level of satisfaction of students from the Penjaskesrek Study Program at Nusa Cendana University in Using ELearning during the Covid-19 Pandemic from the aspect of comfort is included in the Satisfied category.

\section{b. Relationship Aspect}

In the relationship aspect, there are 11 statements answered by respondents, from the 11 statements for communicative indicators between lecturers and students consisting of statements numbered 11 to number 17 , the average percentage of answers is $76 \%$ in the Satisfied category. While the Responsive indicator in serving students consisting of statements number 18 to number 21 obtained an average percentage of answers of $81 \%$ with a very satisfied category. When combined, the average percentage of answers obtained is $78 \%$. Therefore, it can be concluded that the Satisfaction Level of Students of the Physical Education Study Program FKIP Nusa Cendana University in Using E-Learning During the Covid-19 Pandemic from the aspect of the relationship is included in the Satisfied category.

\section{c. Competency Aspect}

In the aspect of competence, there were 18 statements answered by the respondents, from the 18 statements for the Lecturer Reliability indicator in Lectures consisting of statements numbered 22 to number 32 , the average percentage of answers was $78 \%$ in the Satisfied category. While the indicator of student reliability in lectures consisting of statements number 33 to number 39 obtained an average percentage of answers of $71 \%$ with a satisfied category. When combined, the average percentage of answers obtained is $75 \%$. Therefore, it can be concluded that the level of satisfaction of students from the Penjaskesrek Study Program at Nusa Cendana University in Using E-Learning during the Covid-19 Pandemic from the aspect of competence is included in the Satisfied category.

\section{d. Cost Aspect}

In the cost aspect, there were 5 statements answered by respondents, of the 5 statements the indicators described were only on the high cost of the data package consisting of statements number 40 to number 45 . From these answers, the average percentage of answers was 54\% in the less satisfied category. Therefore, it can be concluded that the level of satisfaction of students from the Penjaskesrek Study Program at the University of Nusa Cendana in Using ELearning during the Covid-19 Pandemic from the cost aspect is included in the less satisfied category.

\section{CONCLUSION}

Organizing online lectures during the COVID-19 pandemic is the best solution for the Penjaskesrek Study Program, FKIP University of Nusa Cendana, but it is necessary to pay attention to 4 aspects including the convenience aspect, the relationship aspect, the competency aspect, and also the cost aspect.

Based on the results of the calculation of the average value, it is known that the aspects of comfort, relationship aspects and competence are in the satisfied category. On the other hand, there is one aspect that is found to be slightly different from other aspects, namely the cost aspect, this aspect is included in the less satisfied category. 
Overall, the main results in this study can be concluded that the level of satisfaction of students from the Penjaskesrek FKIP Universitas Nusa Cendana University in Using E-Learning During the Covid-19 Pandemic is in the satisfied category in the comfort aspect, relationship aspect, competency aspect, while the cost aspect can be It was concluded that the Satisfaction Level of Students of the Penjaskesrek Study Program, FKIP University of Nusa Cendana in Using E-Learning During the Covid-19 Pandemic Period. The limitations of this study are that it is only in the scope of physical education and recreation students, and it is possible for future research to explore more broadly in terms of population and samples, within universities and even one province in Indonesia.

\section{REFERENCES}

Arif, Y. (2020). Pelatihan Pengembangan Pembelajaran Olahraga Renang Melalui Model Pembelajaran E-Learning Dan Face-To-Face ( Blended Learning ) Dalam Mata Kuliah. 4(2), 246-252. Http://Www.Jurnal-

Umbuton.Ac.Id/Index.Php/Ppm/Article/ View/630/648

Arif, Y., \& Alexander, X. F. R. (2019). Pengaruh Latihan Plyometric Jump To Box Terhadap Power Otot Tungkai Pemain Bola Voli Pada Tim Putri Penjaskesrek Undana. Jurnal Segar, 8(1), 38-46. Https://Doi.Org/10.21009/Segar/0801.0 5

Fitri, B. M., Widyastutik, O., \& Arfan, I. (2020). Penerapan Protokol Kesehatan Era New Normal Dan Risiko Covid-19 Pada Mahasiswa. Riset Informasi Kesehatan.

Https://Doi.Org/10.30644/Rik.V9i2.460

Fitriani, Y. (2020). Analisa Pemanfaatan Learning Management System (Lms) Sebagai Media Pembelajaran Online Selama Pandemi Covid-19. Journal Of Information System, Informatics And
Computing.

Https://Doi.Org/10.52362/Jisicom.V4i2 .312

Haryanto, S. (2018). Kelebihan Dan Kekurangan E-Learning Berbasis Schoology (Studi Ptk Dalam Pembelajaran Mata Kuliah Academic Listening). Prosiding Seminar Nasional Geotik.

Hasanah, H. (2017). Teknik-Teknik Observasi (Sebuah Alternatif Metode Pengumpulan Data Kualitatif Ilmu-Ilmu Sosial). At-Taqaddum. Https://Doi.Org/10.21580/At.V8i1.1163

Kanal Informasi. (2019). Home» Referensi » Pengertian Instrumen Penelitian Menurut Para Ahli (Arikunto, Sugiyono, Dkk) Pengertian Instrumen Penelitian Menurut Para Ahli (Arikunto, Sugiyono, Dkk). Pengertian Data Primer Dan Data Sekunder.

Kemendikbud. (2020). Surat Edaran Sekretaris Jenderal No.15 Tahun 2020 Pedoman Pelaksanaan Belajar Dari Rumah Selama Darurat Bencana Covid19 Di Indonesia. In Sekretariat Nasional Spab (Satuan Pendidikan Aman Bencana).

Mabesau. (2021). Kuesioner Penelitian. In Angewandte Chemie International Edition, 6(11), 951-952.

Mahnun, N. (2018). Implementasi Pembelajaran Online Dan Optimalisasi Pengelolaan Pembelajaran Berbasis Online Di Perguruan Tinggi Islam Dalam Mewujudkan World Class University. Jurnal Ijiem.

N, Z., Nurmayanti, \& Ferdiansyah, H. (2021). Efektivitas Media Pembelajaran Daring Di Masa Pandemi Covid-19. Jurnal Edumaspul.

Sansen, L. M., Saupe, L. B., Steidl, A., Fegert, J. M., Hoffmann, U., \& Neuner, F. (2019). Daring To Process The Trauma: Using A Web-Based Training To Reduce Psychotherapists' Fears And Reservations Around Implementing Trauma-Focused Therapy. European Journal Of Psychotraumatology. Https://Doi.Org/10.1080/20008198.201 9.1696590

Sattari, A., Abdekhoda, M., \& Gavgani, V. Z. (2017). Determinant Factors Affecting 
The Web-Based Training Acceptance By Health Students, Applying Utaut Model. International Journal Of Emerging Technologies In Learning. Https://Doi.Org/10.3991/Ijet.V12i10.72 58

Setiawan, P. (2020). Pengertian E-Learning Karakteristik, Manfaat, Kelebihan, Kekurangan, Jenis, Komponen, Para Ahli. Guru Pendidikan.Com.

Sugiono. (2016). Metode Penelitian Kuantitatif, Kualitatif Dan R\&D. Bandung: Alfabeta.

Sugiono, P. D. (2014). Metode Penelitian Pendidikan Pendekatan Kuantitatif.Pdf. In Metode Penelitian Pendidikan Pendekatan Kuantitatif, Kualitatif Dan R\&D. Metode Penelitian Kuantitatif, Kualitatif,Dan R\&D, Alfabeta, Cv. (2016).

Yunus, N. R., \& Rezki, A. (2020). Kebijakan Pemberlakuan Lockdown Sebagai Antisipasi Penyebaran Coronavirus Covid-19. Salam: Jurnal Sosial Dan Budaya Syar-I Https://Doi.Org/10.15408/Sjsbs.V7i3.1 5083 